\title{
Introduction: reconsidering European citizenship
}

\section{Sandra Seubert and Oliver Eberl}

\section{TWENTY-FIVE YEARS OF EU CITIZENSHIP}

In the economic and subsequent sovereign debt crisis, not to mention the so called 'refugee crisis', ' the European Union (EU) has not given a convincing impression of its capacity for collective action. The rise of rightwing nationalism and Euroscepticism seem to indicate severe doubts about the functionality and legitimacy of the existing institutional architecture as well as the project of European integration in general. The EU increasingly influences the everyday life of citizens without at the same time increasing its legitimacy to do so. Tacit consent for the course of integration has evaporated: Euro-Europe is divided into the 'core' or 'surplus' countries and the 'periphery' or 'deficit' member states.

One could state that the European project has always been in crisis, that it has grown and survived in an atmosphere of crisis ever since its founding (EC, 2017a: 6). Nevertheless, it seems that this time the crisis goes deeper. It is multidimensional and more wide-ranging in scale: the public finance crisis is in effect a crisis of the common currency which goes along with high levels of political contestation, the consequences of which are more severe than in previous crises (Chalmers et al., 2017: 1-28). This political contestation brings issues of democracy to the table because a thorough public debate on the political implications of the interdependencies arising from the common market and the common currency has long been avoided. Mere coordination of national fiscal policies cast in a stability pact is difficult to achieve without further coordination of fiscal and economic policies. But so far an institutionalised political outlet for the conflicts that arise from these arrangements is missing. In this situation observers describe the European Union as 'entrapped'. What needs to be done (namely some kind of sharing and reallocating burdens and responsibilities within the EU) seems impossible to carry out, and what can be done is ineffective as a way out of the crisis (Offe, 2015: 41-2). In this spirit the President of the European Commission, Jean-Claude Juncker, remarks: 
"We all know what to do but we just don't know how to get re-elected once we have done it" (quoted from Chalmers et al., 2017: 3). What Juncker and Offe make clear is the distance between European decisions and the perspectives of the citizens. This time the crisis goes deeper: it is not only a political crisis about the question of what is to be done (that is, how to solve a common problem); it is also a crisis of the political will of the European-national citizens, who no longer perceive the crisis as a common problem, and maybe no longer care - or, worse, do not want what has to be done to be done.

In 2017, 25 years after the introduction of EU citizenship in the Treaty of Maastricht in 1992, it seems that the EU has 'overstretched' itself with promises of citizenship, because it simply could not provide sufficient measures to improve citizens' social and political lives. Citizens find themselves stuck with a situation in which the nation-state reappears as the only active agent capable of dealing with the problems; yet at the same time they feel that the traditional idea of national sovereignty is evaporating. This creates a dilemma: since the cosmopolitan, pro-European elite has difficulties in convincingly explaining why membership of this Union is worth promoting, disadvantaged citizens from prosperous member states tend to be in favour of putting an end to European integration, whereas less well-off citizens in the Union's deficit countries demand redistributive policies within the Union - which most of their prosperous counterparts are likely to refuse. ${ }^{2}$ It becomes painfully obvious that European citizens are not yet members of a solidly political Union, but that they are still primarily members within a Union of states where national interests are played off against each other.

When EU citizenship was established in the Maastricht Treaty there was already a feeling that the project of European integration was suffering from a deep malaise and public disaffection. Nevertheless, its introduction carried hopes for strengthening the EU's legitimacy. It was supposed to strengthen a 'Europe of citizens' and counterbalance the internal market dispositive. This continuing feeling of malaise first and foremost expresses the lack of political debate in and about Europe. The status of European citizens has always been elusive and complex, determined by courts and political compromise. Public debate on the values of European integration has long been missing, and the social needs of non-mobile citizens in Europe have not been sufficiently addressed in national public debates. Sticking to the 'Westphalian' framing, social justice was still primarily perceived as redistribution between the social classes of one country (Fraser, 2008: 2). This is mirrored in anti-European politics. It scandalises social and political inequality, but misframes it in traditional national ways: protection against the pitfalls of globalisation, so it is claimed, cannot be 
expected to result from a transnationalisation of politics but rather from defending an allegedly 'national self-interest'.

In the post-Second World War era, based on the enlightenment heritage of the democratic revolutions, European nation-states have struggled to overcome this approach to politics. Following the nationalistic atrocities of the 20th century, culminating in German national socialism, the path towards European integration became a collective learning process proclaiming that self-interest 'rightfully understood' should be based on transnational cooperation. However, from its inception the project of European integration was based on a paradoxical idea: sharing sovereignty in order to remain autonomous. Liberal democracies have decided to integrate into a new kind of polity voluntarily in order to maintain and protect their existence as democratic states.

For the concept of citizenship this was an innovative step, but it also had uneasy consequences. Up to that point citizenship had been tied to membership in a national political community. The introduction of EU citizenship pulled towards detaching citizenship from the national. But it also pulled toward detaching it from political space, thus leaving the European citizenry without clear directions for the resolution of social and political conflicts arising from their new interdependency. The apparent 'solution' then is to blame the external actor - the EU. The crisis of European democratic politics and the crisis of European citizenship, therefore, seem to go together.

On the one hand, the crisis of European citizenship seems to be the result of a long-lasting cognitive and moral under-taxing of citizens by political parties that are shying away from the challenge of shaping transnational, pan-European interests and forging border-crossing trust relations. On the other hand, Euroscepticism has existed before; and although it is currently being loudly expressed, it is certainly not the only position that finds its way to the general public on the streets of Europe. With the common aim of countering Euroscepticism, an increasing number of pro-European movements are expressing their concern about a potential disintegration of the EU and calling upon political parties to postpone no longer but to really address necessary reforms for the future. ${ }^{3}$ These movements are practising their EU citizenship in the political sense while trying to mobilise and address a European public as European citizens. Presumably they have understood that a democratic moment in the long intertwined history of European integration between the poles of "Kantian mindset" of democracy and the "managerial mindset" of capitalism might be possible (Brunkhorst, 2015). Dissolution of the Union is not the only option if the citizens take Europe's future into their own hands. ${ }^{4}$

For a long time the executive-driven piecemeal integration of Europe 
could be justified as a success story: for violence and threat as the means of inter-state conflict resolution, the European legal order substituted bargaining and legal adjudication. Likewise, the creation of a common European market fostered national welfare to the benefit of all member states. For the founding generation this legitimising narrative of peace and prosperity associated with the European project was naturally convincing, but it lost power over time. Nevertheless it retained its promise, in particular for the new member states after the Eastern enlargement in 2004. The EU overcame historical hostilities of states by voluntarily increasing their economic and social interdependencies, opening up their borders as well as reaching out to connect democracy and human rights within a new level of political organisation.

Paradoxically, the success of European integration has now become its problem: the more the EU complies with this rationale of transnational integration, the more tensions among the sceptical parts of national publics in the member states increase, which in turn creates barriers for a deeper integration and transnationalisation. Tacit consent for the course of integration was already brought into question before the financial crisis, but has evaporated in the light of more recent conflicts. Coping with the crisis demands effective coordination of social, economic and financial politics; but the member states' peoples can hardly be expected to give up creative power at the national level without there being a clear substitute in sight at the transnational level. That is why the answer to the crisis is unavoidably connected to issues of European democracy. What a European democracy demands is a transnational coding of social conflicts, a border-crossing articulation and deliberation in order to make these issues visible and understandable as transnational economic or cultural lines of conflict. ${ }^{5}$ But what we witness instead is a resurrection of national stereotypes. There is a fatal misframing of social conflicts along national rather than social cleavages. For a democratic re-founding of the European Union by European citizens this misframing has to be broken up.

The downside of piecemeal integration is now also painstakingly obvious to the citizens. However, given the lack of public debate about the EU's political dimension and its transformative effects on national democracies, alternative ways of legitimating the EU are not available. Political imagination has not kept pace with actual integration. The EU generates decisions that both bind its member states and affect the lives of all citizens. But still it is mostly viewed in terms of an international organisation made up of independent sovereign nation-states. It is no wonder then that today many citizens see it as an external agent imposing a legal straightjacket that suppresses national democracy, welfare and prosperity. 


\section{ENCOURAGING POLITICAL IMAGINATION}

How can political imagination help break up this national misframing of conflicts? And what role could EU citizenship play in this respect? We can interpret the populist attack against Europe as a result of the current lack of democratic and social integrative sources. If this is the case, EU citizenship deserves much more attention - politically but also academically. It can be said that the Commission had a sense of that when it announced the call for research on EU citizenship; the project that formed the background to this book was an outcome.

This 'call' suggested that the exercise of EU citizenship is facing barriers that ought to be removed. ${ }^{6}$ The idea of removing barriers mirrors at least symbolically the image of free mobility, free trade, free exercise of rights without hindrances. But what those barriers are and why it is important to remove them is far from self-evident. There is a practical aspect to this question which was certainly an important motivation for the Commission's call. Taking the status quo of citizenship rights in the EU as a starting point, one might ask why people do not make more active use of their rights. Do they lack information? Are there bureaucratic hindrances? Do some (or all) of them not have the necessary social and material resources?

These questions can be empirically researched. But there is another, normative aspect of the questions that is conceptually more demanding and related to deeper dilemmas. How is the status quo of citizenship in the EU to be evaluated? To what extent is citizenship related to the active use of equal rights? What meaning do rights have in the concept of citizenship anyway? How are they related to duties and social practices? It is obvious that pushing the questions in this direction means touching on fundamental problems of current democratic and citizenship theory. It is impossible to analyse the shortcomings of a 'citizenship reality' without any reference to a 'citizenship ideal' - without asking what the promises and prospects of democratic citizenship in general and EU citizenship in particular are. Developing such a citizenship ideal is related very much to the kind of political entity the European Union is supposed to be or become, as well as to the dynamics and directions of its developments. After the constitutionalisation process (initiated by the European Convention on the Future of Europe, 2002/2003) was stopped by referenda in France and the Netherlands, this debate about the finalité of the European Union was pushed to the bottom of the agenda and treated 'like a hot potato'.

The normative aspect of 'barriers' also refers to the intellectual context in which the idea of 'removing barriers' arises. A simple implication could be that barriers are bad and removing them is good. While this is already 
a tendentious picture in the field of economics, it obviously becomes oversimplified and problematic when it is transferred to the political realm. Contrary to the conceptual Hayekian architecture, markets are always 'embedded' in the sense that they are made and allowed to operate by identifiable actors at specific times and locations (Offe, 2015: 7). To interpret this embeddedness as a barrier would strongly express an ideological framing. Markets do not 'happen' naturally; rather, they are shaped and staged by state policies in the sense that the latter guarantee political presupposition for the market to function, for example, property rights, contract rights and currency. The question is not if but how state policies regulate, that is, how markets are politically set in motion. Here the EU comes in: with the four freedoms, a common set of regulatory rules and a common currency it becomes easier for capital to escape political control. Since regulation in the EU is depoliticised, the internal market enhances opportunities to circumvent political debate and exercise economic power through 'exit' moves (Offe, 2015: 13). In this setting removing barriers might well be understood as an attempt to transform "state embedded markets" into "market embedded states" (Brunkhorst, 2014: 446).

The picture of removing barriers becomes even more complicated when we turn to EU citizenship and the challenge of empowering citizens. What is needed to gain support for a transnational model of citizenship is the construction and legitimation of new frames of reference for the deliberation of social and political conflicts. It is unlikely that this constructive challenge can be appropriately addressed in the language of barriers alone. We touch here on the issue of positive rights - rights empowering collective action, the developing of a self-understanding as citizens. Barriers seem to relate to negative rights, the protection from interference. But the creation of political rights is an expression of collective autonomy and can, therefore, not be comprehensively expressed with the idea of removing barriers. The character and current state of European citizenships seems to mirror this tension perfectly well. EU citizenship stands for a unique expansion of citizenship rights; but at the same time it seems to signal its dissolution. It contributes to a disaggregation of the different dimensions of citizenship, collective identity, political membership, access to social rights and benefits. EU citizenship is a move beyond national barriers; but, as far as it is likely to reintroduce a link between economic and political citizenship that the modern welfare state was supposed to overcome, it constitutes a barrier to its democratic character. ${ }^{7}$ The main barrier to EU citizenship is that it detaches citizenship from the national, but so far does not offer a clear, attractive and inclusive substitute at the transnational level. For this reason the concept of EU citizenship should be framed less with the language of barriers and more with the idea of contradictions and constraints. 
The European institutions have brought EU citizenship into being; but their present organisational set-up is also the reason for the defective form of citizenship which constrains its democratic character and reduces it to a rights-based market citizenship. That is why the future of European citizenship is closely connected to the future of European democracy. This future lies between two opposite poles: the dissolution of democratic citizenship and a regression to market privilege, or the completion of European citizenship as democratic citizenship. Can the EU provide what it would need to develop EU citizenship into a democratic European citizenship?

\section{CONTRADICTIONS AND CONSTRAINTS OF EU CITIZENSHIP}

EU citizenship is elusive. In contrast to its historical predecessors, it is difficult to grasp its core 'substance'. The key content of EU citizenship is the right to equal treatment by other political communities. As expressed in the "non-discrimination principle" laid down in the Maastricht Treaty, no EU citizen in any EU member state shall be put in a position more disadvantaged than that of a national citizen or a third-country national. By relating to national citizens, this right to equal treatment constitutes only a relative status of equality for EU citizens: relative to the quality of protection in the respective member state. Particularly with regard to social rights, but also core civil rights as well as political rights, this is tantamount to unequal levels of protection for EU citizens. ${ }^{8}$

But it is not just the elusive and fragmentary character of EU citizenship that leads to questions of contradictions and constraints - problems that are inherently linked to the concept of modern democratic citizenship. What new forms these contradictions have developed in the context of EU citizenship is demonstrated by research results from the bEUcitizen project. It is possible to divide these contradictions along three lines: (1) the contradiction between mobility and rootedness; (2) the contradiction between the citizen as political actor (citoyen) and economic actor (bourgeois); and (3) the contradiction between the universal and the particular. These aspects are expanded upon in what follows.

1. While national citizenship is supposed to be based on a particular link and a certain rootedness in territory, as well as in social and cultural practices, EU citizenship has been intimately linked to citizens' mobility and border crossing. At its core it is a free movement right, a right to mobility. One might interpret this as a chance for citizens to 
expand their conception of the "good life" (de Witte, 2015: 59): As an individual right, mobility extends the opportunities and choices for European citizens beyond the confines of national boundaries. It gives individuals opportunities to leave unfulfilling conditions and look for potentially more meaningful, more prosperous lives elsewhere. This might not only improve their lives materially, but might also transform and enlarge thinking, question usual beliefs, broaden perceptions and ultimately modify views.

From a cosmopolitan perspective the right to move and offer oneself for social interaction is worthy in itself and considered to be a universal human right. As such it ought to be protected by every state, everywhere and for everybody. This already indicates that it is difficult to ground citizenship as an inclusive membership status on the right to mobility alone. ${ }^{9}$ As a human right it cannot principally be restricted. But already in Kant's justification the right to move does not ground any unconditional right to entry. ${ }^{10} \mathrm{~A}$ similar restriction appears in the institution of EU citizenship: it potentially opens the doors for border crossing; it grants a right to visit, a right to offer oneself for economic and social interaction; but it does not grant an unconditional right to residency. The moving citizen ought to be economically self-supporting (or be a family member of an economically self-supporting citizen), a student, a pensioner or a jobseeker, and not become "a burden on the host EU country's social assistance systems". ${ }^{11}$ This leads to the second contradiction between the citizen as a political actor (citoyen) and an economic actor (bourgeois).

2. As a political notion, citizenship refers to a legally constituted membership in a political community and the entitlement to (direct or indirect) participation in a process of self-legislation. In contrast to the political meaning, there is a socio-economic meaning that refers to the member of a particular social class, qualified by possession and economic independence. The political citizen as a law-giver and the citizen as an economically active individual are historically and conceptually related, which gives the idea of citizenship an exclusionary potential (Seubert, 2017). This is mirrored in the systemic tension between a social culture of capitalism (with its values of competitiveness, merit and individual achievements) and a political culture of democracy (with its values of equal worth, respect and cooperation). ${ }^{12}$ In this sense, the socially inclusive practices of 'civicness' stand against the socially exclusive practices of distinctiveness in a bourgeois society. Whereas modern democratic citizenship has finally overcome the dependency of political citizenship on economic status, this dependency casts its shadow in the European context: as demonstrated in 
several reports of the project as well as in contributions to this volume, the connection between citizenship and economic status in the EU is particularly strong.

3. The main challenge of EU citizenship to its modern, state-related counterpart is resolving its tendency to detach citizenship from the national. As a transnational form of citizenship it has a disruptive potential, inherently driven by tension between the particular and the universal. Whereas, on the one hand citizenship always claims to realise equal individual freedom, the practical realisation of these rights, on the other hand, presupposes the existence of institutions which conform to a bounded legal order. Thus, the universalist tendency inherent within the values of equal individual freedom contradicts the particularist conditions of its own realisation: that is, a bounded political community. The founding declarations of modern citizenship open up the idea that - at least potentially - all men and women can be citizens. ${ }^{13}$ They announce general human rights, claiming validity for all and not just for citizens of the constituted political order or some pre-political collectivity. ${ }^{14}$ The universalistic commitment is thus related to two concerns: on the one hand, which universal rights can individuals claim as human beings independent of membership in a community? On the other hand, how can a group of people be defined that can legitimately make particular claims on each other, and thus be entitled to the full range of citizenship rights? This is of particular interest for the challenge of mediating transnational civic solidarity and human rights' cosmopolitan claims. ${ }^{15}$

Whereas contradictions cannot be solved once and for all because they are inherent within the concept itself, constraints refer to those difficulties in the realisation of EU citizenship that are contingent, dependent on historical context, but changeable in accordance with progress and political will. One main constraint results from insufficient EU institutional architecture, which leads to a systematic national misframing of political conflicts. Dominance of the EU's intergovernmental character prevents the development of adequate procedures to deal with this national misframing. Instead of opening up possibilities for balancing the potentially conflicting interests of EU citizens in their double role as EU and national citizens, these arrangements tend to give priority to decisions from the perspective of national citizens. This is not meant as an argument for the putative value of one specific interest or its likelihood of being normatively acceptable; it is rather an argument about the structure of dealing with tension within these potentially contradicting interests. Procedurally there is no possibility of addressing this tension in a way that appeals to the 
enlarged mentality of a European citizen. This is currently manifested as a clash between populist-national interests and European-cosmopolitan interests. The research carried out in this project supports the argument that procedural possibilities influence the way arguments or interests are shaped and presented. It is reasonable to assume, therefore, that the current situation fuels populist views because it fosters discussion from a national rather than a pan-European perspective. ${ }^{16}$

Besides these constitutional constraints, other limitations are caused by the specific historical context and the embeddedness of EU citizenship in many different national cultures, languages and traditions. The major constraint for EU citizenship is its complementary character which links a transnational status to national membership and makes full access to rights dependent on the previous use of mobility rights. These constraints are not absolute and unchangeable; but for the moment they exist and make it more difficult to roll out the normative potential of EU citizenship. More than ten years ago Richard Bellamy, Dario Castiglione and Jo Shaw stated that an idea of democratic inclusion and transnational solidarity is difficult to create in a context of high cultural, economic and institutional diversity (Bellamy et al., 2007: 17). Now, it seems that this was not only correctly observed, but has also even gained dramatic quality. "Making Europeans citizens" has turned out to be a managerial dream which proves that citizens either make themselves or are irrelevant.

\section{OVERVIEW OF THE CHAPTERS}

This book addresses these contradictions and constraints from several disciplinary perspectives, but within a common research context. The chapters elaborate cross-cutting themes that relate to major issues in (EU) citizenship debates. They cover: the challenge of defining appropriate standards for evaluating the political configuration called 'European Union'; the historical evolution and pluralisation of citizenship models; contradictions in the relation between market and political integration; and issues of social citizenship, community and identity as well as prospects for cosmopolitan citizenship. These themes not only relate to ongoing discussions about the future of EU-citizenship but also contribute to new perceptions about its social and institutional context. For these new perceptions the shift from barriers to contradictions and constraints is aimed to be constructive. As outlined above, three main areas of such contradictions are discussed in the chapters: mobility, markets and boundaries. Several contributions elaborate to what extent the fragmentation of EU citizenship that divides political and social rights from civic and economic rights causes constraints 
on the development of European democratic citizenship. Mobility- and market-related access to EU citizenship rights in particular provoke the question of how far a culture of rights without duties and a social contract to back up these rights might be self-defeating.

The book is structured in three parts: the first elaborates models and constructions of EU citizenship; the second deepens understanding of contradictions and constraints, while the third additionally relates them to prospects for the future of European citizenship.

In order to shed light on the construction of EU citizenship, Chapter 1 by Sandra Seubert sets out to analyse the official discourse on EU citizenship, arguing that there are deep dilemmas at work. She relates the debate on EU citizenship to the puzzle of a European political union, and demonstrates how EU citizenship is caught in the 'double loop' of contradictions and constraints: the contradiction between the political language of citizenship and the economic logic of free movement on the one hand and the constraint that arises from the rivalling legitimatory demands of international and supranational forms of political cooperation on the other. The path of expanding European citizenship by embedding the European market through judicial activism has proven to be limited in its success without a political counterpart at supranational level. Seubert argues that such a political counterpart is necessary in order to address problems of justice that arise from the systemic and social interdependencies of the integration process. For the future of EU citizenship, the extent to which the EU succeeds in appropriately channelling pan-European conflicts of wealth disparities and redistribution will prove to be decisive. With regard to EU citizenship, the choice is between a weak, integrated status or a strong(er) differentiated status. While the former tends to undermine substantial equality, the latter tends to undermine formal equality.

In Chapter 2 Marcel Hoogenboom and Maarten Prak analyse the historical origins of local and national citizenship constructions, discussing their implications for EU citizenship. Relations between national and local as well as political and economic dimensions vary significantly between countries. This means that policies to develop an EU citizenship that uses an idealised national citizenship as its frame of reference will inevitably be at odds with the variety of citizenship traditions existing in many countries. At the same time, the pluriformity of Europe's citizenship traditions also provides an opportunity. Connecting new EU citizenship rights with existing national and local rights in the EU member states is in line with historical evidence presented in this chapter. Instead of starting from scratch, therefore, by trying to develop a completely new centralised form of citizenship - erroneously patterned after a model of national citizenship that (arguably with the exception of France) exists nowhere in Europe - the 
EU would perhaps be better advised to acknowledge the national citizenship traditions of its member states and aspire to a multilevel form of citizenship.

Jan Komárek is concerned in Chapter 3 with the duties of EU citizens. Duties of citizenship have been markedly underdeveloped in the European context. The aim of his chapter is to elaborate a conceptual structure for an inquiry into the question of balance between rights and duties related to EU citizenship. It starts from the observation that for some time the absence of EU citizens' duties was interpreted as marking the immaturity of EU citizenship and a major difference from the citizenship of a state. It continues by linking this evaluation first, to more general debates that express dissatisfaction with the current 'culture of rights' and, second, to critique about a lack of conceptual clarity when citizens' duties are invoked in the context of debates on EU citizenship. The question of what their justification can possibly be relates to ongoing debates on the EU's very legitimacy, where the liberal focus on rights is often criticised at the expense of communitarian or republican values focusing on collectivity rather than individuality. Komárek suggests that a solution needs to be found somewhere between the two: inspired by republican-liberal positions from political theory, he seeks to 'translate' the general theoretical arguments into the context of debates concerning EU citizenship.

Part II about the contradictions and constraints of EU citizenship opens with Frans van Waarden, who in Chapter 4 addresses conflicting social logics in the dynamics of European integration. These two sources are the 'market' and the 'polis'. Van Waarden describes the common historical origins and the different social logics of the market and the polis. He relates these issues to the context of European cooperation and integration, critically reconstructing the founding history of the EU: the hope that integration of national markets into one single European market would produce shared material interests and, in turn, prevent any major future inter-state conflicts as the first half of the 20th century had seen. Economic cooperation and integration was considered easier to realise than political integration, as it affected national autonomy and sovereignty less directly. Some 60 years later European integration through the further internationalisation of markets has increased the choice for consumers, workers and investors. However, in the polis the influence of choice has been reduced. Liberalisation and privatisation policies have diminished the authority of political actors. It is concluded that a liberalisation policy, carried to the extreme as either libertarian or anarchic, leaves no more room for a political domain, no more role for the state, for oikos or politeia - which would be a real 'tragedy of the commons'.

In Chapter 5 Hartley Dean examines the relation of EU citizenship to 
work, and describes tensions between formal and substantive equality in Europe. Dean asks when and under what circumstances can the EU citizen be in any sense more than a market actor? To what extent are workers across Europe truly citizens, as opposed to merely factors of production? And to what extent can those across Europe who are not or cannot be engaged in the labour market truly be equal citizens? He argues that these questions have general relevance for the terms under which EU citizens can have rights to equality of treatment and parity of participation in the public sphere. How might EU citizens, whether 'at home' within their own country or migrants within Europe, be assured of: meaningful equality of social recognition and respect; substantive equality of experience in relation to their access not only to privately provided goods and services, but also provision of, and protection by, public services; and effective equality of engagement, not only within civil society but also in democratic consultation and decision-making processes at neighbourhood, local, national and EU level?

In Chapter 6 Christoph Strünck analyses the ambiguous relation between rights and citizenship in the EU, together with the potential of EU citizenship to transform consumer rights into consumer citizenship. He holds that the relationship between citizenship and rights in general is ambiguous: any concept of citizenship rests on rights, whereas rights do not necessarily constitute citizenship. The European Community has shaped rights for quite a long time. The treaties constitute rights of free movement and citizenship, the European Court of Justice (ECJ) extracted fundamental rights from member states' shared traditions; and through directives a range of statutory rights have been crafted, for instance consumer rights and worker rights as well as other economic and social rights. There is a controversial debate on why rights have become a prominent tool in European integration. The two main driving forces are side effects from the single European market and political fragmentation at EU level. As the European market developed, so it was found that the traditional way of informal policy-making and insider networks in the EU no longer worked. Thus more formal and legalistic rules proved to be an equivalent that helped maintain the growing market sphere. Furthermore, powerful European actors tried to overcome the obstacle of fragmented policy-making and multiple principal-agent problems by delivering rights.

The role of shifting borders on communities and identities in Europe and the quest for republican EU citizenship and polity are analysed by Vít Hloušek and Viktor Koska in Chapter 7. They elaborate a framework for their analysis by expanding the traditional understanding of citizenship as membership of a particular political community. In order to encapsulate the various roles as well as possible struggles and challenges that stem 
from the existence of competing identities during the new nation-state formations and/or changes of the boundaries of existing polities, the analysis strives for a more comprehensive study of citizenship regimes. This approach makes it possible to focus on various non-formal and formal areas of social life in which issues of identity and inclusion/exclusion to a polity are prominent. Considering the building of European identity, Hloušek and Koska argue that it is vital to develop EU standards of legal protection concerning human rights' issues that are not perceived as concurring with domestic standards and that will not create conflict between popular perceptions regarding national state and EU roles.

In Chapter 8 Francis Cheneval and Mónica Ferrín address the question of whether or not EU citizenship can integrate multilayered identities. Their starting point is that EU citizenship has introduced much complexity with regard to who is an insider and who is an outsider. While the EU has tried to provide equal treatment to nationals who live in another member state, strict limitations have been enforced on third-country citizens who move to an EU country. This different treatment has resulted in different categories of citizens - a situation that is often difficult to manage. Cheneval and Ferrín propose a comparison between several case studies and the European Union. It assumes that the comparative history of citizenship provides rich examples of multilevel citizenship in theory and practice, although such examples are today often forgotten or obscured by the dominant narrative of single and homogeneous, territorial, state-based citizenship. It is argued that the varieties of multilevel citizenship can shed some light on possible developments for European citizenship which can help overcome some of the obstacles Europeans face nowadays when trying to exercise their rights as citizens.

In Chapter 9 Sandra Seubert addresses and evaluates EU citizenship under the lens of cosmopolitanism. The chapter has a double interest: by reconstructing cosmopolitan principles it aims; first, to discuss the question of whether or not transnationalisation is a step towards a realisation of cosmopolitanism; and, second, to propose a relationship with the development and prospect of EU citizenship as an example of the attempt to transnationalise (citizenship) rights. The cosmopolitan frame of reference is aimed at helping to assess the EU's prospects and challenges as a transnational membership regime. Seubert argues that a cosmopolitan standpoint generates inherent tension for the EU: even if EU citizenship moves towards a transnational form, as a federation of states it is still a bounded entity - bounded through the borders of its member states. It is proposed, therefore, that we should think of cosmopolitanism, both in EU and global contexts, not as something static and fixed but rather as a transformative process - cosmopolitisation. 
In Chapter 10 Oliver Eberl addresses the problem of transnational solidarity, and argues that a European form is possible. Contrary to positions which assume that pre-political cultural identity precedes civic identity, he argues that the process that generates solidarity moves in the opposite direction: civic identity is the result of democratic institutions. Eberl shows that the exclusive transnational realisation of solidarity by European member states creates paradoxes that constrain a European form. Transnational solidarity is 'parasitic' to national solidarity. Without loosening this dependence, European solidarity will always be trapped in the paradox of subsisting transnational mobility by national solidarity which constrains the emergence of European solidarity. What is needed is a supranational layer of social rights in the form of direct payments to individuals, which will overcome the contradictory structure of transnational mobility of EU citizens and national solidarity of state citizens that the idea of easier access to national social welfare systems by EU citizens cannot really solve. Furthermore, the idea of leaving all social services in member states' hands rather provokes intensified negative reactions to transnational mobility.

The dispute about 'more or less Europe' is also reflected in Chapter 11, in which Philippe Van Parijs sets out to 'justify Europe'. He argues that we need a European Union, a common market, a European public authority, a European democracy for reasons of social justice, and that we must be prepared to pressure, to protest and to march in the streets for that as we did in our respective nation states. He shows why the European Union suffers at the moment from criticism of a democracy deficit, and gives recommendations on how to transform the EU into a real demos-cracy. The problem for Europeans trying to mobilize across borders is that they do not share a common language. But the spread of English as a lingua franca supports the hope that they will be able to talk to each other, and that the EU is not bound to drift into ever-greater injustice.

It is finally concluded that the EU is still torn between market and polis, leaving the situation negligently undecided as to whether it should be developed into an instrument of catching up with economic and cultural globalisation or as an accelerator of it. As long as the standards by which the political configuration called 'European Union' is to be evaluated remain so deeply contested, the status of EU citizenship is kept normatively indeterminate. But the formal existence of EU citizenship indicates its potential transformation into a polity whose constituent elements are no longer just the member states. For this transformation, mobility as the core of EU citizenship and the protection of rights as the driver of EU citizenship's further development are not sufficient to address the promises 
of citizenship. Reconsidering EU Citizenship is, therefore, interpreted as empowerment rather than protection. Four areas of such empowerment are sketched in the Conclusion: (1) reclaiming constituent power; (2) deconstitutionalising the treaties; (3) enhancing direct legitimation - empowering a transnational parliament; and (4) accomplishing a transnational citizenship status.

With this volume we aim to add further input to a debate which will investigate various paths to how European citizens can be empowered as EU citizens.

\section{NOTES}

1. Which is in fact a humanitarian crisis and a crisis of democracy (Brunkhorst, 2016): proof of the Dublin system's complete failure.

2. It is remarkable that left-wing protest movements in debtor states such as Spain or Greece and the majority of the population in these countries are not 'anti-European' in general and not in favour of an exit from the EU; rather, they are against austerity politics, which they identify primarily with Germany. Exit options are instead articulated in the relatively well-off member states. For an instructive differentiation of the Northern European New Right, a Central-East European defensive nationalism and a Southern European pro-European and pro-refugee New Left, see Kriesi, 2016.

3. For example, Demokratie in Bewegung (change.org/brauchtbewegung): "Wir wollen einen Neuanfang für Gerechtigkeit und Demokratie." As Eurobarometer Trends show, most EU citizens feel European and see themselves as European citizens. Interestingly, they identify more with this status than with 'the EU' as such. See Cheneval and Ferrín, Chapter 8 in this volume, and EC, 2017b: 11.

4. Rainer Bauböck (2017: 2) tries to put this observation into a more general context by explaining that, historically, transformations of confederations into federations were dependent on existential crisis.

5. In the EU's institutional architecture the European Parliament (EP) is the actor most likely to articulate and win recognition for transnational social interests, while the European Commission is supposed to be a neutral power, guardian of the treaties; the European Council is an organ that deals with political conflicts but tends to code them along lines of national interest. One of the difficulties for the EP in fulfilling its function is a lack of social intermediaries - civil society actors to pass the conflicts negotiated in Parliament on to the various democratic peoples. This points to the need for a European political space. See Seubert et al., forthcoming and Gaus and Seubert, 2016.

6. FP 7 SSH Call 2012 Activity 5, 'Challenge: Exercise EU Citizenship: Removing Barriers' (http://ec.europa.eu/research/participants/data/ref/fp7/89485/h-wp-201201_en.pdf).

7. See Seubert and Eberl, 2018.

8. As the situation in certain East European member states demonstrates (see Granger, 2018).

9. For a reflection on this challenge see Hloušek and Koska, Chapter 7 in this volume.

10. See Seubert, Chapter 9 in this volume.

11. EC, Memo/1/1041(http://europa.eu/rapid/press-release_MEMO-13-1041_de.htm).

12. See van Waarden, Chapter 4 in this volume.

13. See Seubert and Eberl, 2018.

14. See Seubert, Chapter 9 in this volume.

15. See Eberl, Chapter 10 in this volume.

16. See Seubert et al., forthcoming. 


\section{REFERENCES}

Bauböck, Rainer (2017), 'Still United in Diversity? The State of the Union Address, 5 May 2017', accessed 17 May 2017 at https://stateoftheunion.eui.eu/wp-content/up loads/sites/8/2017/05/The-State-of-the-Union-Address-Still-United-in-Diversity. pdf.

Bellamy, Richard, Dario Castiglione and Jo Shaw (2007), 'Introduction: From National to Transnational Citizenship', in Richard Bellamy, Dario Castiglione and Jo Shaw (eds), Making European Citizens: Civic Inclusion in a Transnational Context, Basingstoke: Palgrave Macmillan, pp. 1-28.

Brunkhorst, Hauke (2014), Critical Theory of Legal Revolutions: Evolutionary Perspectives, New York: Bloomsbury.

Brunkhorst, Hauke (2015), 'European Crisis: The Kantian Mindset of Democracy under Pressure of the Managerial Mindset of Capitalism', in Hauke Brunkhorst, Charlotte Gaitanides and Gerd Grözinger (eds), Europe at a Crossroad: From Currency Union to Political and Economic Governance?, Baden-Baden: Nomos, pp. $60-87$.

Brunkhorst, Hauke (2016), 'Für eine demokratische Neugründung Europas: Die "Flüchtlingskrise" als Rückkehr des Verdrängten', Blätter für deutsche und internationale Politik, 9, 63-74.

Chalmers, Damian, Markus Jachtenfuchs and Christian Joerges (eds) (2017), The End of the Eurocrat's Dream: Adjusting to European Diversity, Cambridge: Cambridge University Press.

De Witte, Floris (2015), Justice in the EU: The Emergence of Transnational Solidarity, Oxford: Oxford University Press.

European Commission (2017a), White Paper on the Future of Europe: Reflections and Scenarios for the EU27 by 2025, COM (2017) 2025, https://europa.eu/europe an-union/sites/europaeu/files/whitepaper_en.pdf.

European Commission (2017b), 'Citizenship Report, 2017: Strengthening Citizens' Rights in a Union of Democratic Change', http://ec.europa.eu/newsroom/docu ment.cfm?doc_id $=40723$.

Fraser, Nancy (2008), Scales of Justice: Reimagining Political Space in a Globalizing World, Cambridge, UK/Malden, MA, USA: Polity Press.

Gaus, Daniel and Sandra Seubert (2016), 'Report on Voter Turnout for the European Parliament and Political Equality in the EU', accessed 7 July 2017 at http://beuci tizen.eu/wp-content/uploads/D8.6-Report-on-voter-turnout-for-the-EuropeanParliament-Political-Equality-in-the-EU_31.3.16.pdf.

Granger, Marie-Pierre (2018), 'The Protection of Civil rights and Liberties and the Transformation of Union Citizenship', in Sandra Seubert, Marcel Hoogenboom, Trudie Knijn, Sybe de Vries and Frans van Waarden (eds), Moving Beyond Barriers: Prospects for EU Citizenship?, Cheltenham, UK and Northampton, MA, USA: Edward Elgar Publishing, Chapter 9.

Kriesi, Hanspeter (2016), 'The Politicization of European Integration', Journal of Common Market Studies, 54 (S1), 32-47.

Offe, Claus (2015), Europe Entrapped, Cambridge, UK/Malden, MA, USA: Polity Press.

Seubert, Sandra (2017), 'Antinomies of European Citizenship', in Jürgen Mackert and Bryan S. Turner (eds), The Transformation of Citizenship, Vol. 2, London/ New York: Routledge, pp. 135-51. 
Seubert, Sandra and Oliver Eberl (2018), 'Boundaries and Promises: Conflicts of Democratic Citizenship and Its Prospects in the European Union', in Sandra Seubert, Marcel Hoogenboom, Trudie Knijn, Sybe de Vries and Frans van Waarden (eds), Moving Beyond Barriers: Prospects for EU Citizenship?, Cheltenham, UK and Northampton, MA, USA: Edward Elgar Publishing, Chapter 2.

Seubert, Sandra, Oliver Eberl and Daniel Gaus (forthcoming), 'Political Inequality and Democratic Empowerment in the European Union: The Role of the European Parliament', in David Levi-Faur and Frans van Waarden (eds), Democratic Empowerment in the European Union, Cheltenham, UK and Northampton, MA, USA: Edward Elgar Publishing. 